\title{
Czy joga może być „sztuką życia”? Przegląd badań na temat jogi jako zjawiska społecznego
}

\author{
Agata Stasińska \\ Instytut Psychologii Polskiej Akademii Nauk
}

DOI: http://dx.doi.org/10.18778/1733-8069.16.4.09

Słowa kluczowe:

joga, relacje

interpersonalne,

krytyczne studia nad jogą, joga jako zjawisko społeczne, socjologia rodziny, socjologia intymności, dobrostan psychiczny

\begin{abstract}
Abstrakt: Praktyka jogi jest coraz bardziej popularną formą aktywności fizycznej zarówno w Polsce, jak i na świecie. Wpływa na poprawę stanu zdrowia, ale i stanowi element rozwoju osobistego i często także praktykę duchową. Badania na temat praktyki jogi zdominowane są jednak przez nauki o zdrowiu, zaś w naukach społecznych głównie przez psychologiczne badania oparte o techniki ilościowe, które często mają trudność w uchwyceniu zniuansowanej relacji ciało-umysł, obecnej w doświadczeniu praktyki jogi. Rzadko podejmuje się także próby zbadania związku praktyki jogi z budowaniem relacji społecznych przed jednostkę.

Celem artykułu jest przybliżenie polskim czytelnikom i czytelniczkom pól badawczych, gdzie obecnie zgłębia się praktykę jogi jako zjawiska społecznego. Przyglądam się jodze jako fenomenowi historyczno-społecznemu. Przede wszystkim jednak przyglądam się badaniom na temat wpływu praktyki jogi na jednostkę, jak i podejmujących się krytycznego oglądu społeczności jogicznych, by zakończyć na studiach podejmujących temat związku praktyki jogi z relacjami interpersonalnymi. Podsumowując swój przegląd, przedstawiam także rekomendacje dla przyszłych badań na temat praktyki jogi.

Artykuł może stanowić inspirację dla przyszłych badaczy i badaczek zainteresowanych praktyką jogi jako zjawiskiem społecznym, na przykład socjologów i socjolożek reprezentujących zróżnicowane dziedziny socjologii, takie jak socjologia rodziny, intymności i pary, ale także sportu, medycyny czy religii.
\end{abstract}

Agata Stasińnka, socjolożka i adiunkta w Instytucie Psychologii PAN. W latach 2013-2016 badaczka w projekcie badawczym Rodziny z wyboru w Polsce. W latach 2016-2020 badaczka w projekcie DOING RIGHT(S): Nowoczesne narzędzia dla profesjonalistów i profesjonalistek pracujacych z rodzinami LGBT+. Absolwentka ISNS UW, gdzie w 2017 uzyskała tytuł doktora nauk społecznych. Autorka książki Socjologia Pary. Praktyki intymne w zwiazkach nieheteroseksualnych (2018). Współredaktorka numerów specjalnych czasopism takich jak „Sexualities” czy „Studia Socjologiczne”. Autorka artyku- łów z zakresu socjologii rodziny, intymności, pary i seksualności, opublikowanych w czasopismach takich jak „Gender, Place and Culture”, „Sociological Reseach Online”, „Sexualities”. Od wielu lat aktywnie uczestniczy w obserwacji świata jogi.
Adres kontaktowy:
Instytut Psychologii Polskiej Akademii Nauk
ul. Jaracza 1, 00-378 Warszawa
e-mail: astasinska@psych.pan.pl 
J

oga jest coraz bardziej popularną formą aktywności fizycznej w Polsce1. W 2015 roku praktykowało ją około 300 tys. osób (Czapiński, Panek 2015). W 2018 na świecie społeczpraktykujących jogę obejmowała ponad 300 milionów ludzi (Montigny 2016). Joga postrzegana jest przez ćwiczących jako aktywność łącząca ciało i umysł (83\%), sposób na poprawę zdrowia (70\%) i forma rozwoju osobistego (66\%) (bosonamacie.pl 2016).

Joga ma udokumentowane skutki w zakresie zdrowia fizycznego (Szopa 2008; Grabara 2017) i psychicznego (Ross i in. 2014; Field 2016; Grabara 2017). $\mathrm{W}$ naukach społecznych prowadzi się rozbudowane, głównie ilościowe, badania na temat wpływu praktyki jogi na jednostkę jedynie $\mathrm{w}$ dziedzinie psychologii, niewiele jest natomiast studiów na ten temat $\mathrm{w}$ dziedzinie socjologii, antropologii czy mniej znanej w Polsce geografii człowieka (human geography).

W polskiej socjologii również nie poświęcono wiele uwagi związkowi praktyki jogi z życiem społecznym jednostki, zaś jedyną pracą na ten temat wyróżniającą się zakresem tematycznym i pogłębioną analizą jest książka Krzysztofa Koneckiego dotycząca między innymi tego, jak praktykujący jogę konstruują tożsamość ,jogiczną" i postrzegają własne ciało, a także, jakie są cechy społeczności jogicznej w Polsce oraz efekty praktyki jogi dla samych praktykujących (Konecki 2012). Niemniej jednak można śmiało stwierdzić, że zarówno w polskich, jak i światowych badaniach społecznych wciąż bardzo rzadko podejmuje się problematykę związku prak-

${ }^{1} \mathrm{~W}$ tytule artykułu odnoszę się do bliskiej mi koncepcji „,sztuki życia” autorstwa Michela Foucaulta, podkreślającej wartość praktyk dbania o siebie jako praktyk służących zmianie społecznej (patrz: Foucault 2010). tyki jogi i życia społecznego oraz relacji interpersonalnych jednostki, czy to w sferze prywatnej, czy publicznej.

Istnieją natomiast istotne przesłanki do podjęcia takich badań. Wyniki studiów dotyczących zdrowia psychicznego wskazują, że w porównaniu z ogółem populacji osoby ćwiczące jogę są bardziej odporne na stres, realistyczniej oceniają napotkane trudności, cechują się większym spokojem wewnętrznym i lepszym samopoczuciem, łatwiej podejmują decyzje, są bardziej świadome własnego ciała, mają lepsze kontakty interpersonalne (Ross i in. 2014; Field 2016; Grabara 2017). Można zatem przypuszczać, że taka charakterystyka ćwiczących może w znaczący sposób wpływać na ich relacje społeczne i interpersonalne, wymaga to jednak badawczego zgłębienia, szczególnie że badań w tym obszarze jest stosunkowo niewiele (Ross i in. 2014; Kishida i in. 2018; Konecki 2018a; Evron 2019; Kishida i in. 2019).

Niniejszy artykuł stanowić zatem będzie przegląd najważniejszych badań dotyczących szeroko rozumianego związku praktyki jogi z życiem społecznym jednostki. Moim celem jest zatem przybliżenie polskim badaczom i badaczkom najważniejszych przedsięwzięć badawczych związanych ze społecznym wymiarem praktyki jogi i wskazanie istniejących w nich luk, które mogą wypełnić przyszłe badania. Temat artykułu lokuje się na przecięciu różnych nurtów socjologii z jednej strony rodziny (Szlendak 2010), intymności (Bieńko 2013) i pary (Schmidt i in. 2018; Stasińska 2018), z drugiej zaś sportu (Jakubowska 2009; Jakubowska, Nosal 2018) i medycyny (Ostrowska 2019).

We wstępnej części artykułu przedstawię główne informacje na temat tego, czym jest joga i jak kształtuje się jej współczesne rozumienie $\mathrm{w}$ odniesieniu 
do ewolucji historycznej pojęcia. W zasadniczej części zaś przedstawię najważniejsze pola badawcze dotyczące praktyki jogi w ujęciu społecznym. W ostatniej części przedstawię własne wnioski i rekomendacje dla przyszłych badań na temat jogi, które mogą zainteresować badaczy i badaczki społeczne w Polsce.

\section{Społeczne, historyczne i kulturowe konteksty współczesnej jogi}

Joga współcześnie w świecie zachodnim definiowana jest przez pryzmat praktyk fizycznych (joga posturalna) oraz medytacyjnych (joga medytacyjna) (de Michelis 2005). Jak twierdzi religioznawczyni i badaczka jogi Matylda Ciołkosz (2020), kluczem do zrozumienia zjawiska jogi jest uznanie jej zróżnicowanego charakteru. Ciołkosz wskazuje, że joga jest zarówno zjawiskiem starożytnym, jak i nowoczesnym, zaś spektrum praktyk, które można określić mianem jogi, odnosi się zarówno do tego, co dziś rozumiemy jako gimnastykę, jak i medytację. Ponadto stanowi ona także niezależny od religii system filozoficzny i duchowy.

Praktyki jogiczne przez setki lat stanowiły część zarówno jogi klasycznej, jak i występowały jako istotna część praktyk religijnych i niezliczonych form jogi ludowej, a nawet chrześcijańskich czy hebrajskich (Jakubczak 1999), albowiem w najszerszym rozumieniu jogą można określić całe bogactwo praktyk służących do duchowego doskonalenia się. Praktyki jogi nie są jednak praktykami religijnymi, chociaż wiąże się z nimi przekonanie o istnieniu możliwości osiągnięcia doświadczenia transcendencji. Joga obiecuje zatem osiągnięcie takiego stanu umysłu, w którym człowiek transcendować może doświadczenia życia codziennego i w którym zyskuje zdolność pełniejszego wglądu $\mathrm{w}$ istotę rzeczywistości. Same praktyki jogiczne, w tym asany, wywodzą się ze stworzonych przez rozmaite grupy buddystów, dżinistów i ascetów starożytnych praktyk ascetycznych mających na celu zdyscyplinowanie ciała (Mallinson, Singleton 2017).

Współczesna joga odwołuje się do tradycji starożytnych, których celem było wyzwolenie jednostki z koła kolejnych narodzin - samsary. Zgodnie z filozofią jogi było to możliwe za pomocą szeregu praktyk ascetycznych, które miały na celu ujarzmienie ciała. Dzięki temu, jak wskazał Patańdźali - autor najbardziej znanego traktatu stanowiącego największe dzieło o jodze klasycznej spisanego około 200-500 wieku n.e. pt. „Patandźalajogasastra", joga umożliwia powściągnięcie poruszenia świadomości (jogaś citta vritti nirodha) (za Iyengar 2011: 69). Patańdźali pisze między innymi o systemie filozoficznym jogi - jodze ośmiostopniowej, która obejmuje zarówno nakazy i zakazy moralne (jamy i nijamy) mające na celu kontrolę zachowania jednostki, jak i pozycje jogiczne (asany), które mają przygotować do kolejnych stopni jogi koncentrujących się kolejno na: kontroli oddechu (pranajama) kontroli zmysłów (pratjahara), jak również kontroli procesów mentalnych: koncentracji (dharana), głębokiej medytacji (dhjana) i stanu wyzwolenia (samadhi). Późniejszy okres od 500 r. n.e. aż do XIX wieku nazywa się w historiografii okresem poklasycznym. W tym czasie rozwinęło się wiele różnorodnych tradycji jogicznych, takich jak między innymi buddyzm tantryczny, tantryzm czy śiwaizm, a także dewocyjnych ruchów związanych z bhakti jogą. Natomiast około 1000 roku n.e. można mówić o wyłonieniu się hatha jogi. Współcześnie $\mathrm{w}$ ramach hatha jogi praktykuje się dziesiątki, a nawet setki asan (pozycji jogicznych), chociaż w samych Jogasutrach Patańdżali pisał jedynie 
o kilkunastu pozycjach, w których jogin powinien odczuwać wygodę i stabilność, by móc rozpocząć dalsze praktyki oddechowe i medytacyjne. Natomiast nauczyciele i nauczycielki, którzy po dzień dzisiejszy rozwijają hatha jogę, stworzyli całe bogactwo pozycji, dzięki którym można nie tylko wzmocnić i rozciągnąć ciało, ale także zadbać o zdrowie fizyczne i długowieczność.

Najnowszy okres rozwoju jogi zaczyna się od początku XVII wieku i kolonizacji Indii przez Wielką Brytanię. W XIX wieku w odpowiedzi na zachodnie zainteresowanie duchowością Wschodu Europę Zachodnią zaczęli odwiedzać nauczyciele z Indii; często mówi się więc, że w ostatnich 150 latach hatha joga rozwijała się $\mathrm{w}$ wyniki interakcji ludzi Zachodu zainteresowanych hinduskimi religiami oraz mniej lub bardziej zwesternizowanych Hindusów (de Michelis 2005: 2). W ostatnich dwóch wiekach na Zachodzie zaczęły się rozwijać rozmaite podejścia czy szkoły jogi o bardzo zróżnicowanym charakterze w zależności od osoby nauczyciela, która inspirowała rozwój danego podejścia. Współcześnie można spotkać zatem jogę skierowaną na praktyki głęboko duchowe i medytacyjne, sięgające na przykład do starożytnej bhakti jogi, ale także zlaicyzowane formy praktyki jogi posturalnej, skoncentrowane na praktyce asan (hatha joga).

Naturalnie więc rozwój jogi posturalnej sprzęga się z rozwojem kultury fizycznej na Zachodzie. Szczególnie w XX wieku można mówić o bardzo dużym rozwoju i wzroście popularności jogi posturalnej, szczególnie pod wpływem uczniów Tirumali Krishnamacharyi - hinduskiego nauczyciela hatha jogi, nazywanego ojcem współczesnej jogi. To właśnie jego uczniowie, tacy jak Pathabi Jois i B.K.S. Iyengar, a także jedna z pierwszych znanych nauczycielek jogi Indra Devi odwiedzali w XX wie- ku Europę Zachodnią i stali się największymi popularyzatorami współczesnej jogi posturalnej, ich nauki dały początek bogactwu współczesnych podejść do jogi o bardziej synkretycznym charakterze. O ile w świecie zachodnim wciąż z trudem przychodzi uznanie, że hatha joga nie jest tylko narzędziem dbania o zdrowie fizyczne, ale również przyczynia się dobrostanu psychicznego i rozwoju duchowego jednostki, to zarówno starożytne teksty na jej temat, jak i nauki współczesnych nauczycieli takich jak Jois i Iyengar zawsze odnosiły się do duchowej siły praktyki asan.

Obecnie najbardziej rozpowszechnioną formą jogi posturalnej we współczesnym świecie jest joga według metody B.K.S. Iyengara (de Michelis 2005: 194). Specyfika jego podejścia odnosi się przede wszystkim do dużego nacisku na uważność i precyzję wykonywanych asan, które służą budowaniu większej świadomości ciała, stabilności i równowagi w pracy poszczególnych części ciała. Z czasem praktyki wzrasta dojrzałość jogina i jego głębsze doświadczanie działania poszczególnych asan i przeniesienie uwagi z peryferyjnego ciała do wewnątrz, doświadczając nowej jakości praktyki i rozwijając samoświadomość i doświadczenie asany na poziomie fizycznym, organicznym i mentalnym. Podejście Iyengara charakteryzuje się ponadto wykorzystywaniem różnorodnych pomocy (m.in. pasków, klocków, koców, krzeseł), które służą umożliwieniu osobom o różnych stopniu elastyczności i siły doświadczenia działania poszczególnych asan. W tymże podejściu duże znaczenie ma również praca nauczyciela, który demonstruje kolejne pozycje, ale także używa precyzyjnej korekty słownej i manualnej, aby umożliwić uczniom pełniejsze doświadczenie asany i pogłębienie świadomości ciała, a także bezpieczną i niekontuzjogenną praktykę. 
Współcześnie joga stanowi zróżnicowane zjawisko społeczne. Ciołkosz (2020) wskazuje, że w szerszym rozumieniu joga $w$ jej najnowszym okresie jej rozwoju łączona była także z celem w postaci przemiany społecznej. Badaczka zwraca uwagę, że charakter tej zmiany może być wieloraki, i o ile w XX-wiecznych Indiach wykorzystywana była jako narzędzie w programach nacjonalistycznych (o czym najszerzej pisał Mark Singleton i jego współpracownicy [Singleton 2010; Mallinson, Singleton 2017]), o tyle współcześnie często łączy się ją raczej z lewicowymi programami zmiany społecznej, a zatem z większą społeczną odpowiedzialnością, ekologią, troską o dobro klimatu czy zwierząt.

Niewątpliwie jednak we współczesnym świecie Zachodnim i globalnej Północy często łączy się ją z praktyką fizyczną nakierowaną na szeroko rozumiany dobrostan psychiczny i fizyczny, i jako taka podlega ona również prawom rynku i logice konsumpcjonizmu (GlobeNewswire 2020). Chociaż w Polsce rynek ten tak naprawdę dopiero się rozwija, to na świecie wyceniany jest na ponad dziesiątki, a nawet sto milionów dolarów (Lewis 2008; Montigny 2016). Często więc dyskutuje się o kwestiach związanych z dostępnością zajęć jogi dla osób o niższym statusie finansowym, a także kwestii jakości proponowanej oferty zajęć, nastawionych często na zysk finansowy, czy też znaczenia rosnącego rynku akcesoriów i ubrań prezentowanych jako niezbędne do praktyki.

\section{Joga w perspektywie nauk społecznych}

Jako socjolożkę specjalizującą się $\mathrm{w}$ technikach jakościowych i badaczkę seksualności i bliskich związków interesuje mnie, na ile praktyki jogi, a w szczególności popularnej hatha jogi (a zatem jogi posturalnej), łączy się z relacjami społecznymi jed- nostki, czy to w sferze prywatnej, czy publicznej. Patrząc z tej perspektywy, przeglądałam zarówno piśmiennictwo anglojęzyczne, jak i polską literaturę przedmiotu, przy czym to pierwsze jest daleko bardziej rozbudowane. Niewątpliwie społeczne studia nad jogą zdominowane są przez nauki psychologiczne, w większości oparte na badaniach ilościowych, podejmujące się zbadania wpływu praktyki różnorakich form jogi na zdrowie psychiczne jednostki. Ponadto jodze jako zjawisku społecznemu przyglądają się również badacze i badaczki związane ze studiami krytycznym (critical yoga studies), prowadzący analizy z perspektywy grup społecznie wykluczanych, a zatem z perspektywy rasy, płci czy seksualności. $W$ ramach tego nurtu podejmuje się również analizy funkcjonowania społeczności jogicznych, biorąc pod uwagę znaczenie tychże społeczności dla osób do nich należących, jak również kwestię indywidualnej i zbiorowej tożsamości joginów, promowany i reprodukowany system wartości i dynamikę relacji wśród uczestników zajęć, a także relacji między uczniami a nauczycielem. Niewiele jest natomiast badań na temat tego, jak regularna praktyka jogi łączy się z kształtowaniem relacji interpersonalnych i przemianami związków intymnych. $\mathrm{W}$ dalszej części artykułu przybliżę najważniejsze wyniki badań z poszczególnych zarysowanych tu pól badawczych w obrębie społecznych studiów nad jogą. Nie jest moim celem sztywne określenie tych pól jako rozdzielnych czy też wyczerpujących bogactwo badań na temat praktyki jogi, sugeruję zatem, by czytelnik lub czytelniczka potraktowali niniejszy przegląd jako podyktowany moimi badawczymi zainteresowaniami.

$\mathrm{Na}$ potrzeby zaprezentowanego $\mathrm{w}$ artykule przeglądu literatury przejrzałam kilkaset artykułów dotyczących związku praktyki jogi (szczególnie 
jogi posturalnej, jako że ta najczęściej jest przedmiotem badań) ze zdrowiem fizycznym, psychicznym i życiem społecznym. Kryteriami selekcji artykułów, które zdecydowałam się opisać w niniejszym artykule, były: 1) artykuł lub książka musiały być recenzowane, 2) opublikowane $\mathrm{w}$ latach 1990-2020, 3) badanie dotyczyło praktyki jogi.

Na podstawie lektury tytułów i streszczeń artykułów, a także tego, jaką metodologię stosowano w badaniu, poddałam dalszej dokładnej lekturze kilkadziesiąt artykułów naukowych, odrzucając te, które dotyczyły zdrowia fizycznego i nie odnosiły się do aspektu zdrowia psychicznego czy kwestii społecznych. Wybrane artykuły obejmują szerokie spektrum związku jogi z życiem społecznym jednostki, szczególnie uwzględniając te, które mogą być przydatne $\mathrm{w}$ analizie praktyk relacyjnych jednostki (Morgan 2011; Bieńko 2013; Stasińska 2018; Sikorska 2019). Szczególną uwagę przywiązywałam do tych, które opierają się na metodologii jakościowej (Denzin, Lincoln 2009), chociaż jest ich mniej niż opartych o badania ilościowe.

\section{Wpływ praktyki jogi na dobrostan psychiczny}

Jednym z głównych wyzwań w badaniach nad dobroczynnym wpływem jogi jest określenie jednej definicji operacyjnej jogi. Jak już wskazałam we wprowadzeniu do niniejszego artykułu, na świecie współcześnie praktykuje się bardzo wiele różnych stylów jogi. W zachodniej literaturze naukowej termin , joga” jest bardzo ogólny, obejmuje szereg praktyk umysł-ciało, takich jak pozycje jogiczne (asany), medytacja (dhjana) i kontrola oddychanie (pranajama) (Parshad 2004; Ospina i in. 2007). Przy czym to właśnie medytacja i uważność i koncentracja na wrażeniach płynących z ciała są szczególnie powiązane z większą umiejętnością regulacji emocji
(Menezes i in. 2015) i poczuciem integracji umysłu i ciała (Uebelacker i in. 2010). Wydaje się zatem, że szczególnie taka praktyka asan, która skierowana jest na rozwinięcie świadomości doświadczanych wrażeń fizycznych i psychicznych, może mieć dobroczynny wpływ na psychikę ćwiczących, niemniej jednak w badaniach, które zaraz przytoczę, joga jest przede wszystkim rozumiana jako praktyka asan i dominuje w nich koncentracja na jej fizycznym wymiarze, z którego wywodzone są efekty dla dobrostanu psychicznego, nie zaś rozumienie jogi jako praktyki z założenia rozumianej jako mającej duchowy, psychologiczny charakter.

Najbardziej rozwinięte pole badań psychologicznych na temat wpływu praktyki jogi na zdrowie psychiczne dotyczy kwestii radzenia sobie ze stresem oraz stanami depresyjnymi. Pośród badań ilościowych warto wyróżnić te, które posługiwały się techniką kontrolowanej interwencji, badając poziom stresu po i przed odbyciu intensywnego kursu jogi przez nowicjuszy.

W kompleksowym przeglądzie 35 badań dotyczących jogi i depresji zespołu pod kierownictwem Karen Pilkington (2005) badaczki doszły do wniosku, że interwencje oparte na jodze mogą mieć potencjalnie korzystny wpływ na zaburzenia depresyjne. W jednym z opisanych przez nie badań grupa młodych osób doświadczających niewielkich objawów depresyjnych została zaproszona do udziału w 5-tygodniowym programie interwencji jogi Iyengara, zaś po jej zakończeniu osoby badane zadeklarowały znaczące zmniejszenie objawów depresji i lęku w stosunku do grupy kontrolnej, która nie brała udziału w kursie (Woolery i in. 2004). Z kolei w badaniu zespołu Andreasa Michalsena (2005) grupa kobiet doświadczających na co dzień wysokiego poziomu stresu uczestniczyła w 12-tygodniowym 
kursie, specjalnie dopasowanym do ich potrzeb jogi, metodą Iyengara. Analizując swoje wyniki, autorzy podali w wątpliwość, czy uzyskane przez nich wyniki dowodzące pozytywnego wpływu na redukcję stresu mają faktycznie związek z praktyką jogi, czy też były po prostu związane z satysfakcją związaną z uczeniem się trudnych i nowych pozycji jogicznych i zaangażowaniem w kurs oraz samym wysiłkiem fizycznym, który, jak dowodzą rozmaite badania z zakresu nauk o zdrowiu, wpływa dodatnio na poczucie szczęścia jednostki.

W celu dokładniejszego przyjrzenia się temu, czy i w jaki sposób to właśnie joga wpływa na redukcję stresu i radzenie sobie ze stanami depresyjnymi zespół badawczy Patricii Ann Kinser (2013) przeprowadził badanie, w którym także zastosowano kurs interwencji jogą, ale tym razem nie zbadano uczestniczek cierpiących na depresję za pomocą kwestionariuszy, lecz wywiadów semiustruktyzowanych. Dzięki zastosowaniu metodologii jakościowej możliwe było nie tylko stwierdzenie pozytywnego wpływu praktyki (czego dowodzą najprościej badania ilościowe), ale także uzyskanie informacji o tym, w jaki sposób kobiety postrzegały wpływ praktyki jogi na ich życie i zdrowie psychiczne. $Z$ badań tych wynika, że joga stanowi dla praktykujących przede wszystkim sposób na zadbanie o siebie. Uczestniczki badania wskazały, że dzięki jodze uczyły się radzić sobie ze stresem i trudnościami związanymi z rozpamiętywaniem problemów, budowały poczucie siły i kompetencji, a także wzrastało ich poczucie samoakceptacji. Badane Kinser i innych opowiadały, w jaki sposób zajęcia jogi wspierały uczestniczki badania w wyjściu z domu i budowaniu relacji z innymi dzięki poczuciu wspólnotowego doświadczenia z innymi uczestniczkami zajęć, które miało miejsce w bezpiecznej i przyjaznej przestrzeni, co znacząco wpłynęło na zmniejszenie się ich poczucia samoizolacji. Wiele badaczy i badaczek potwierdza również, że joga oddziałuje poprzez swoją bliskość z technikami treningu uważności, koncentracji, otwartości i akceptacji (mindfulness) (Bishop i in. 2004) i wzmacniaja poczucie kompetencji (Smith, Alloy 2009). Poza korzyściami dla zdrowia psychicznego płynącymi z wysiłku fizycznego badacze zwracają uwagę na istotność pracy z oddechem, szczególnie ważnej podczas praktyki asan, jak i technik pranajamy, które wpływają na aktywację parasympatycznego układu nerwowego (Shastri i in. 2017). Ponadto istotne również może być stosowanie praktyk medytacyjnych i relaksacyjnych, które wpływają na redukcję reakcji na stres (Benson 1975; Kinser i in. 2012; Gotlib, Hammen 2015; Vempati, Telles 2016). Z kolei większa świadomość własnego ciała może przekładać się na większą autorefleksyjność jednostki i budowanie świadomości własnych emocji. Dla osób biorących udział we wspomnianym badaniu Kinser i innych istotne było również doświadczenie poczucia bezpieczeństwa i troski podczas zajęć ze strony nauczyciela jogi, które wpływa na zaangażowanie społeczne i reakcję układu limbicznego (Porges 2009). Z kolei z innych badań wynika, że dla cierpiących na depresję poczucie troski ze strony nauczyciela jest szczególnie ważnym czynnikiem facylitującym proces leczenia (Granek 2006; Rhodes, Smith 2010). Warto także wspomnieć, że w odróżnieniu od na przykład studiów fitnessu czy siłowni studia jogi w założeniu są zaprojektowane, aby wzmagać poczucie spokoju i wyciszenia uczestników zajęć (Andrews i in. 2004; Hoyez 2007).

Szereg badaczy i badaczek podejmuje się również prób sprawdzenia, w jaki sposób praktyka jogi wpływa także na zdrowie psychiczne osób niecierpiących na żadne poważniejsze problemy czy zaburzenia psychiczne. $Z$ ich studiów wynika, że 
regularna praktyka jogiczna w połączeniu z praktyką uważności wpływają pozytywnie na samoregulację emocjonalną (Morone i in. 2012; Sauer-Zavalai in. 2013; Friese, Hofmann 2016), z czasem czyniąc ją również bardziej bezwysiłkową (Gard i in. 2014; Goleman 2015). Regularna praktyka wpływa również na wyższy poziom współczucia i wzrost autorefleksyjności (Sauer-Zavala i in 2013).

Interesujące wnioski z badań pojawiły się również w obszarze kwestii stosunku do własnego ciała i cielesności praktykujących. Erich Schiffmann i Trish O'Rielly (1996) zwracają uwagę, że ze względu na to, że jedną z najważniejszych umiejętności w jodze jest wyczucie, jak daleko wejść w daną pozycję tak, aby z jednej strony rozwijać fizyczne granice (zakres ruchu, wzmocnienie i rozciągnięcie mięśni), z drugiej zaś nie doznać kontuzji, to praktyka jogi uczy słuchania i docenienia informacji zwrotnych pochodzących z ciała. Z tego względu, dzięki zwiększonej świadomości i zdolności reagowania na sygnały pochodzące z ciała, praktykujący może zwracać uwagę na swoje wewnętrzne odczucie cielesności i zdolności fizyczne, zmniejszając tym samym znaczenie wyglądu fizycznego dla koncepcji indywidualnej tożsamości. Nie powinno zatem dziwić, że praktykujący jogę mają większą świadomość własnego ciała, traktują swoje ciało mniej przedmiotowo, są bardziej usatysfakcjonowani ze swojego wyglądu i mają mniej zaburzeń odżywania w porównaniu z grupą osób ćwiczących podczas zajęć aerobowych (Daubenmier 2005; Pilkington i in. 2005).

\section{Społeczności jogiczne w perspektywie krytycznych studiów nad jogą}

W ostatnich latach rozwinęły się badania na temat społeczności praktykujących jogę na świecie.
Przyczynkiem do nich są wyniki badań, w których stwierdza się, że im dłuższa i intensywniejsza praktyka, tym bardziej subiektywnie doświadczane są pozytywne skutki regularnej praktyki (Impett i in. 2006). Stąd szereg badań podejmuje temat tego, co motywuje ludzi do regularnej praktyki jogi. Z badań Clary Lewis wynika, że głównymi motywacjami praktykujących jogę były kwestie związane z jasnością umysłu, rozwijaniem współczucia i poczuciem spokoju (Lewis 2008), stąd często zwraca się uwagę na to, że joga jako fenomen międzykulturowy stanowi metodologię prowadzenia dobrego życia (living a good life) (Strauss 2002). Mając za podstawę praktyki cielesne, tradycja jogiczna na poziomie jednostkowym jest łatwo łączona $z$ dbaniem o zdrowie fizyczne. Istotne jednak jest to, że tradycyjnie rozwój fizyczny stanowił podstawowy i pierwszy krok dla jednostki, który służył jej pełniejszemu i wartościowemu uczestnictwu w większej wspólnocie społecznej. Sarah Strauss pisze zatem o reorientacji jogi polegającej na połączeniu nowej teorii ze starą praktyką i widzi w niej nadzieję na przekroczenie esencjalizujących dychotomii, takich jak Wschód/ Zachód, religia/nauka, naród/świat. Jej zdaniem praktykujący poprzez łączenie różnych elementów z obu kręgów kulturowych tworzą dynamiczny model dobrego życia podzielany przez wyobrażoną i często realną wspólnotę praktykujących jogę na świecie (Strauss 2002).

W obrębie krytycznych studiów nad jogą często podejmuje się także refleksje badawcze na temat uwikłania Zachodniej praktyki jogi z regułami współczesnego kapitalizmu i inkluzywności studiów i szkół jogi, a także charakterystyki społeczności jogicznych na świecie. Postuluje się przy tym konieczność zwrócenia uwagi na to, co powstrzymuje przed uczestnictwem w zajęciach mężczyzn i grupy mniejszościowe i dyskryminowane (Ross i in. 
2013; Berila 2018). Same osoby praktykujące jogę na Zachodzie dostrzegają także, że biorąc pod uwagę współczesne warunki i tempo życia, praktyka jest możliwa pod warunkiem przynależności do określonej klasy społecznej, ze względu na to, że jest ona stosunkowo czasochłonna i wymagająca regularności (zwykle zajęcia jogi trwają od godziny do 2 godzin, tymczasem standardowe zajęcia aerobowe do godziny, widoczne na poziomie fizycznym efekty widać po miesiącach i latach praktyki). Zatem to raczej osoby należące do klasy średniej lub wyższej moga pozwolić sobie na regularne uczestnictwo w zajęciach jogi, znajdując przestrzeń na wypoczynek, mogą stworzyć warunki dla duchowego rozwoju (Childress 2007).

Szczególnie w kontekście amerykańskim, gdzie można mówić o najbardziej rozbudowanym rynku jogi, sporo uwagi poświęca się zjawisku komercjalizacji jogi, znajdującej odzwierciedlenie w pojawieniu się instruktorów-celebrytów, konkursów, linii ubrań, pakietów podróżnych, diet i różnorodności ofertowej rozmaitych zajęć jogi, których głównym celem jest komercyjny zysk, niekonieczne zaś promowanie praktyki duchowej (Markula 2014). Wiąże się to z charakterystyką demograficzną grupy obecnych i potencjalnych praktykujących jogę, obejmującą głównie białe, zamężne, wykształcone i zatrudnione kobiety z klasy średniej, których zasoby finansowe i habitus rynek śmiało eksploatuje (Lewis 2008; Markula 2014), zniechęcając jednocześnie do praktyki tych którzy, nie chcą lub nie są w stanie przeznaczyć na nią większych środków finansowych (Bhasin 2013 za: Smith, Atencio 2017). Badacze i badaczki zwracają uwagę, że popularność studiów jogi często łączy się z miejską gentryfikacją (Smith, Atencio 2017). Wspomina się także, że znakomita większość praktykujących jest biała i w wielu regionach rzadko kiedy studia jogi od- wiedzają Afroamerykanie czy osoby z klasy robotniczej (Roro 2012 za: Smith, Atencio 2017).

Z badań Nancy Atkinson i Rachel Permuth-Levine (2009) wynika jednak, że tylko nieliczni praktykujący jogę zwracają uwag na bariery finansowe związane z praktyka, chociaż badaczki wskazują także na stereotyp wskazujący, że joga jest dyscypliną przeznaczoną dla kobiet ze względu na ich rzekomą większą elastyczność, co sprawia, że mężczyźni w świecie zachodnim rzadziej decydują się na jej praktykę. Zjawisko to ma miejsce poniekąd w sprzeczności z normami Wschodu, bowiem w tradycyjnej praktyce jogi mającej swe źródło w Indiach joga jest raczej praktykowana przez mężczyzn. Dopiero w XIX i XX wieku zajęcia jogi otwarto dla kobiet, w czym dużą rolę mieli Krishnamacharya i jego uczniowie i uczennice, szczególnie Indra Devi. Co ciekawe jednak, dla samych praktykujących, szczególnie osób nienormatywnych płciowo lub seksualnie (np. należące do społeczności LGBTQ), praktyka jogi stanowi dużo mniej płciowo czy społecznie normatywną formę aktywności niż sporty wymagające znacznej sprawności fizycznej, ćwiczenia aerobowe czy treningi na siłowni (Atkinson 2010), skierowane w znacznej mierze na rozwój fizyczny i rywalizację (Lewis 2008).

Krytycznie do zjawiska „okupacji” praktyki jogi przez neoliberalizm podchodzi także Verena Schnäbele (2013), która wskazuje na związek między rozumieniem jogi jako „bodźca do ciągłej transformacji, samodoskonalenia" a neoliberalnymi wartościami "ciężkiej pracy, samodzielności i indywidualizmu”" (Schnäbele 2013: 186 [tłum. własne]). W swojej analizie argumentuje ona, że w świecie jogi ciało może być instrumentalnie wykorzystywane do kreowania jednostki jako produktywnej, wydajnej, zdrowej i wolnej od stresu. 
Prowadzone są również studia na temat dyskursów, które kształtują współczesną jogę i tego, na ile są one uznawane i reprodukowane przez praktykujących jogę. Pirkko Markula (2014) przeanalizowała okładki znanego pisma Yoga Journal z ostatnich 35 lat. Sugeruje ona, że joga jest często przedstawiana jako holistyczny sposób życia, który jest niezbędny do przeciwdziałania negatywnym skutkom wysokiego tempa życia i chorób cywilizacyjnych. Badaczka kontestuje ten obraz, wskazując, że w rzeczywistości „styl życia jogi został zaprojektowany w celu maksymalizacji szczęścia poprzez przemyślane dbanie o siebie" (Markula 2014: 166 [tłum. własne]), co w znacznej mierze dystansuje ją od tradycyjnego ujęcia, w którym uznawano jogę za praktykę budowania świadomości społecznej niezbędnej do tworzenia relacji i wspólnot wrażliwych na „kwestie społeczne, kulturowe i środowiskowe" (Markula 2014: 165 [tłum. własne]). Dla Markuli oznacza to, że ,jogiczne ja” stanowi de facto owoc "przedsiębiorstwa neoliberalnego", wzmacniając logikę samodzielnej i przedsiębiorczej jednostki (Markula 2014: 166 [tłum. własne]). W swoich pracach Markula $(2004$; 2014) wprost sięga do teorii Michela Foucaulta, wskazując, że neoliberalizm określa, w jaki sposób jednostki w jodze są postrzegane jako „racjonalny aktor ekonomiczny, biorący odpowiedzialność za dbanie o siebie" (Foucault 2008 za Markula 2014: 150 [tłum. własne]), z czym wiążą się określone zasady postępowania.

Badaczka mimo dostrzeżenia szeregu pozytywnych wartości promowanych przez dyskurs „Yoga Journal", między innymi troskę o środowisko naturalne i relacje interpersonalne, zwraca uwagę na jego głębokie uwikłanie w reguły współczesnego neoliberalizmu. Szczególnie krytykuje go za apolityczność przy jednoczesnym promowaniu zaangażowania w dobro wspólnot. Upatruje w tym ryzyko tego, że istotniejsze staje się dobro jednostki niż wrażliwość na krzywdę, dyskryminację i wykluczenie społecznych innych. Brakuje jej również na łamach czasopisma większego krytycyzmu wobec kultu zdrowego i pięknego ciała oraz komercjalizacji jogi, szczególnie widocznej w amerykańskim kontekście kulturowym.

Zainspirowani teorią Foucaulta byli również Sabrina Smith i Mathew Atencio (2017), którzy przeanalizowali, jak dyskurs jogi wpływa na jednostkę poprzez skoncentrowanie się na tym, jakie znaczenia i wartości przypisują jodze sami praktykujący. Z ich badań wynika, że trudno określić praktykę jogi jako jednoznacznie ekskluzywną czy inkluzywną. Badani stwierdzili bowiem, że joga może być ekskluzywna, jednak jest to w gestii jednostki, poszczególnych nauczycieli i polityki studiów i szkół jogi, by przezwyciężyć wykluczenie społeczne związane z dostępem do praktyki. Badani Smith i Atencio wskazują, że joga jest narzędziem troski o siebie, ale sami badacze podają $\mathrm{w}$ wątpliwość bezkrytycyzm osób badanych. Ich zdaniem joga może potencjalnie uprzywilejować pewne formy ucieleśnienia integralnie związane z białą kobiecością klasy średniej i wpływać negatywnie na osoby uważane za „inne” (ze względu na kolor skóry, rozmiar ciała czy status klasowy) (Smith, Atencio 2017). Badacze zwracają uwagę, że wpływy neoliberalistycznych wzorów funkcjonowania jednostki są bardzo wyraźne w wypowiedziach badanych. Stawiają zatem śmiałe pytanie o to, w jaki sposób społeczno-kulturowa analiza jogi może przyczynić się do ujawnienia i stworzenia nowych form praktyki. Zastanawiają się, na ile praktykujący jogę mogą krytycznie zająć się problemami społecznymi, aby stworzyć bardziej inkluzywne ramy praktyki i zwiększyć uczestnictwo $\mathrm{w}$ zajęciach jogi różnorodnych grup społecznych 
(Smith, Atencio 2017: 1180). Podsumowując swoje rozważania, sugerują konieczność zgłębienia, czy istnieje precedens dla bardziej świadomego społecznie podejścia do praktyki jogi.

W badaniach z nurtu critical yoga studies zwraca się również uwagę na to, że doświadczenie poczucie wzmocnienia (empowerment), które daje jednostce praktyka jogi, zależne jest od szeregu społecznych, materialnych i dyskursywnych okoliczności, w których odbywa się praktyka. To, na ile będzie ona $\mathrm{w}$ istocie doświadczeniem duchowym i odczuwana na poziomie psychicznym, nie zależy jedynie od indywidualnej determinacji, ale także od warunków życia czy jakości bliskich więzi praktykujących. Klas Nevrin (2008) omawia, w jaki sposób skupienie się na zwiększonej świadomości doznań cielesnych i emocji podczas praktyki jogi wpływa na to, jak praktykujący rozwija koncepcję tego, kim jest i czym jest dla niego joga. Nevrin podkreśla, jak ważne jest to, jakie uczucia budzi nie tylko sama praktyka, ale okoliczności (miejsce praktyki i nauczyciel) dla samego doświadczenia jogi. Zwraca uwagę, że czynniki te często są decydujące dla wyboru szkoły jogi czy też kontynuacji praktyki lub decyzji o jej podjęciu w danym miejscu i z danym nauczycielem. Wskazuje, że doświadczenie wzmocnienia związane z przynależnością do pewnej społeczności kształtującej się wokół szkół czy nauczycieli jogi również zależne jest od emocji, które wiążą się z daną przestrzenią i relacjami. Nevrin wskazuje, że wspólna praktyka jogi może mieć cechy rytuałów interakcyjnych wywołujących, dzięki wspólnym praktykom ucieleśnienia, poczucie przynależności, zaufania, pewności i ekscytacji (Nevrin 2008). Odnosi się on również do koncepcji emocjonalnych wspólnot Michela Maffesoliego (1996 za: Nevrin 2008), zgodnie z którą wywołują one poczucie indywidualnej witalności, intymności i bliskości z innymi. Badacz ponadto dostrzega we wspólnej praktyce jogi szansę na stworzenie warunków do oporu wobec tradycyjnych form uspołecznienia. Jednocześnie jednak przestrzega przed ryzykiem kultu indywidualizmu i wskazuje na konieczność podkreślenia wartości wspólnotowych, relacyjności i współzależności. Widzi on szansę na stworzenie prawdziwie otwartej wspólnoty jogicznej, jednak jedynie jeśli obecni w niej nie będą replikować hierarchicznych struktur, w którym jedynie jednostki będące na piedestale (nauczyciel czy zaawansowani praktykujący) mogą czerpać emocjonalne korzyści. Podobnie jak Markula także Nevrin zwraca uwagę na wciąż dominującą $\mathrm{w}$,"świecie jogi" tendencję do kultu zdrowego trybu życia i unikanie trudnych tematów i świadomości społeczno-politycznej, w czym widzi ryzyko reprodukcji normatywnych ideałów i osłabienia refleksyjności jednostki.

Nieco na marginesie głównego nurtu studiów krytycznych nad jogą sytuują się badania, w których także inspirowano się teorią Foucaulta, jednak odnosząc się bardziej do indywidualnego aspektu doświadczenia jogi. Jennifer Lea przeprowadziła kilka badań etnograficznych opartych o wywiady i obserwację uczestniczącą (Lea 2009; Lea i in. 2016) dotyczących doświadczenia praktyki jogi w życiu codziennym joginów i joginek w Wielkiej Brytanii. W jednym z nich, posiłkując się również wynikami autoetnografii, analizuje, w jaki sposób praktyki troski o siebie w rozumieniu Foucaulta obecne są także w wizji i praktyce jogi B.K.S. Iyengara (Lea 2009). Mimo swej własnej identyfikacji jako jogini i pozytywnych doświadczeń związanych z regularną pogłębioną praktyką jogi, badaczka stawia pytanie, na ile obietnica wyzwolenia obecna $w$ jodze i wyrażona $\mathrm{w}$ wielu pismach Iyengara i klasycznych tekstach jogicznych, począwszy od Joga- 
sutr Patańdżalego, może być realizowana dzięki praktyce, a na ile praktyka nie stanowi jedynie sposobu na wyuczenie jednostki nowych wzorców ruchu, zachowania i przeżywania rzeczywistości, i w rezultacie ogranicza podmiotowość i wolność ja (Lea 2009).

Istotnym wątkiem rozważań Lei jest też stwierdzenie, że obecna w myśleniu ludzi Zachodu logika progresu nie ma zastosowania w przypadku praktyki jogi, której celem nie jest po prostu odtworzenie kształtu danej asany, lecz głębsze jej doświadczenie i ciągłe rozwijanie uważności i koncentracji oraz inteligencji ciała. Zdaniem Lei (2009) postrzeganie swoich doświadczeń jedynie poprzez to, na ile prawidłowo wykonuje się daną asanę, czy też, czy umie się wykonać zaawansowane pozycje, a nie odczuwanie działania asany i zauważanie, na ile pogłębia ona nasze rozumienie własnego ciała i własnego ja prowadzić może jedynie do opisywania swojej praktyki w kategoriach destruktywnej narracji porażki.

Badaczka, odnosząc się do filozofii jogi oraz teorii Foucaulta, znajduje łączący je mianownik, który wskazuje na wartość tworzenie relacji ze sobą, opartej o stosunek troski, a nie wiedzy. Wykształcenie takiej postawy wobec siebie i świata stanowi terapeutyczny walor praktyki jogi, który owocuje w dalszej konieczności prozdrowotnymi skutkami dla dobrostanu psychicznego i fizycznego. Badaczka rozumie znaczenie jogi poprzez jej zdolność przeciwstawiania się sposobom, w jakie współczesny świat tłumi świadomość i pozbawia jednostkę cielesnej inteligencji, na co zwraca uwagę zarówno Foucault, jak i Iyengar.

Lea tłumaczy, że dzięki praktyce asan jednostka uczy się przyjmować aktywny stosunek wobec sie- bie i świata, wymykać się sztywności wymuszanej na niej przez praktyki dominacji i relacje władzy, by uzyskać elastyczność niezbędną do uzyskania szczęścia w życiu. Widzi zatem w praktyce jogi „wezwanie polityczne, które skłania jednostkę, by nie pozwolić (społeczno-kulturowym ekonomiom) świata kierować działaniami bez refleksji nad tym procesem" (Lea 2009: 85 [tłum. własne]). Tłumaczy ona, że podstawą do tworzenia owej aktywnej, autentycznej i opartej na współczuciu relacji ze światem i samym sobą jest kształcenie uważności. W czasie zajęć jogi wykształca się ona dzięki skierowaniu uwagi na to, co jednostka może zrobić w stosunku do samej siebie, a nie co wydaje jej się, że powinna być w stanie zrobić w stosunku do innych osób na zajęciach. Zdaniem Lei ten aspekt praktyki jogi realizuje postulaty Foucaulta związane $\mathrm{z}$ terapeutycznym potencjałem praktyk troski o siebie dla jednostki funkcjonującej w świecie społecznym (Lea 2009: 85).

Na koniec badaczka wskazuje, że czerpanie z potencjału praktyki musi odbywać się w zgodzie i kontakcie ze sobą. Pogłębianie otwarcia, budowanie samoświadomości, rozwijanie uważności nie może odbywać się w sposób radykalny i nadmierny, ale także winno pozostać odważne i zdecydowane, konieczne jest zatem zachowanie autokrytycyzmu i autorefleksji w pracy nad sobą i rozwojem umiejętności, realizując każdą praktykę jogi jako praktykę troski (Foucault 2001 za: Lea 2009: 87). Podobnie jak Nevrin i Markula Lea także (2009) zwraca uwagę na konieczność społeczno-kulturowej analizy praktyki jogi, uwzględniając kwestię jej dostępności, a nie jedynie abstrakcyjnych korzyści dla jednostki. Badaczka podkreśla, że praktyka jogi jako praktyka troski o siebie stanowi przywilej, który podlega potencjalnej opresyjności struktur społeczno-kulturowych, stąd też konieczne jest 
zachowanie wrażliwości na kwestię wykluczenia i nierówności społecznych obecnych także w społecznościach joginów i joginek.

Niewątpliwie perspektywa krytyczna w badaniach nad współczesną praktyką jogi jest bardzo potrzebna. Wrażliwość na społeczne wykluczenia także jest niezwykle ważna, bowiem może skłonić tworzących normatywne i instytucjonalne ramy praktyki jogi (międzynarodowe i narodowe stowarzyszenia jogi i grupy nauczycieli) do refleksji nad warunkami, w których promują oni praktykę jogi. To, czego brakuje jednak badaniom $\mathrm{z}$ tego nurtu, to $\mathrm{z}$ jednej strony dostrzeżenie już istniejących mechanizmów przeciwdziałania wykluczeniom w społecznościach jogicznych, z drugiej zaś przedstawienie propozycji rozwiązań dla problemu wykluczenia.

\section{Praktyka jogi a relacje interpersonalne}

Ostatni dział badań społecznych poświęconych praktyce jogi, który wyodrębniłam, dotyczy jogi w kontekście budowania relacji interpersonalnych, w tym bliskich więzi, takich jak związki intymne. Pole tychże badań jest stosunkowo mało rozbudowane, można usytuować je poniekąd pomiędzy psychologicznymi badaniami skupionymi na dobrostanie jednostki a wyżej zarysowanymi krytycznymi studiami nad jogą i wspólnotami praktykujących jogę. To właśnie na tym polu badaczki i badacze szczególnie dostrzegają potrzebę prowadzenia badań metodami jakościowymi lub też w planie mieszanym, łącząc badania ilościowe i jakościowe. Zastosowanie takich podejść badawczych wiąże się ze specyfiką relacji ciało-umysł i trudnością w zmierzeniu oddziaływania praktyk uważności i współczucia obecnych w czasie praktyki jogi na funkcjonowanie jednostki $\mathrm{w}$ relacjach interpersonalnych (Kishida i in. 2018).
W badaniu zespołu Moe Kishidy (2018) zastosowano otwarte kwestionariusze i wywiady pogłębione z praktykującymi jogę o różnym doświadczeniu $\mathrm{w}$ praktyce. Celem badania było lepsze zrozumienie, w jaki sposób praktykujący jogę postrzegają relacje ze sobą i innymi i jakie są efekty praktyki jogi w ich życiu i relacjach interpersonalnych. Osoby badane wskazały na to, że regularna praktyka wpływa na wytwarzanie spokojnych stanów umysłu, uważność, współczucie (dla siebie) i poczucie więzi (Kishida i in. 2018), co skutkuje większą samoakceptacją i obniżeniem reaktywności emocjonalnej. Kishida i inni wskazują, że wrażenia te mogą być osiągane dzięki treningowi przechodzenia od stanu napięcia do stanu relaksacji. Przejście to jest stale obecne $\mathrm{w}$ praktyce jogi i zgodnie z teorią poliwagalną (Lucas i in. 2016) wpływa na umiejętność autonomicznego systemu nerwowego do autoregulacji emocjonalnej i osiągniecia relaksu niezbędnego do zachowania sprawnych funkcji poznawczych. Badani wskazywali także na wzmocnienie uważności dzięki jodze, które obecne jest podczas praktyki jogi na macie, ale także po za nią, także w czasie interakcji społecznych. Badani wspominali także, że praktyka jogi skłania ich do kultywowania współczucia i życzliwości. Odnosząc się do wartości społeczności praktykujących jogę, mówili też o poczuciu więzi, chociaż nie do końca byli w stanie wskazać, jak praktycznie ono powstaje. $Z$ badań na temat wpływu ruchu na więzi społeczne wynika, że sam fakt wspólnego i zsynchronizowanego poruszania się i imitowania ruchów nauczyciela przyczynia się na poziomie fizjologicznym do budowy poczucia więzi z innymi uczestnikami zajęć (Mehta i in. 2016). Zespół Kishidy przygląda się także ograniczeniom własnego badania, które są o tyle interesujące, że sygnalizują możliwy i pożądany kierunek przyszłych studiów na temat subiektywnego wpływu praktyki jogi na 
relacje interpersonalne jednostki. Kishida i inni zwracają uwagę na to, że grupa przez nich badana nie była szczególnie zróżnicowana pod względem demograficznym. Wskazują również, że nie podjęły się zbadania, na ile na relacje interpersonalne wpływa stosowanie się przez osoby badane do pierwszych dwóch członów jogi, czyli jam i nijam, które często w sposób bezpośredni stanowią kompas moralny dla praktykujących.

W następnym badaniu wykonanym przez zespół Kishidy (2019) podjęto się próby opisania i analizy bezpośredniego i pośredniego wpływu praktyki jogi na relacje interpersonalne. Tym razem grupę ponad 100 osób badanych poproszono o pisanie dzienniczka w postaci otwartego kwestionariusza, w którym przez 21 dni codziennie opisywały one swoje doświadczenia na temat funkcjonowania w relacjach interpersonalnych i praktyki jogi. Z badania wynika, że w dni, kiedy osoba ćwiczyła więcej jogi niż zwykle, raportowała większe poczucie uważności i współczucia wobec siebie. Mimo że z innych studiów wynika, że współczucie wobec siebie wpływa na obniżenie niepokoju, rozpamiętywania i tendencji do samokrytyki (Neff i in. 2007), to zespołowi Kishidy nie udało się stwierdzić bezpośredniego związku między praktyką jogi i relacyjnym funkcjonowaniem jednostki. Badaczki wskazują, że aby uchwycić, na ile joga wpływa na więzi społeczne, być może konieczne jest dłuższe studium i objęcie analizą także osób poczatkujących, a także przyjrzenie się, na ile dana osoba dokonuje rzeczywistych aktów współczucia, a nie jedynie raportuje subiektywnie współczucie wobec innych. Kishida i współpracowniczki rozważają również konieczność dokładniejszego przyjrzenie się cechom charakterologicznym badanych osób. Na koniec podkreślona została jednak siła badań jakościowych w naturalnych warunkach życia co- dziennego osób praktykujących jogę, wskazując, że dzięki temu udaje się uzyskać wiedzę o uwspólnionym i realnym doświadczeniu praktykujących w kontekście społeczno-kulturowym.

Z kolei w badaniu zespołu Alyson Ross (2014) badaczki podjęły się analizy treści prawie dwustu wypowiedzi uzyskanych w dużym przekrojowym badaniu jogi na grupie ponad 1000 praktykujących według metody B.K.S. Iyengara joginów i joginek dotyczących tego, jak praktyka poprawia jakość relacji międzyludzkich. Osoby badane stwierdziły, że dzięki jodze doświadczyły osobistej przemiany, zwiększyły się ich interakcje społeczne, lepiej radzą sobie także z trudnościami w relacjach i utratą bliskich więzi. W ich opinii dzieje się to na skutek zmiany życiowego nastawienia i perspektywy, bowiem praktyka jogi czyni ich bardziej cierpliwymi, miłymi, uważnymi i samoświadomymi osobami. Często wspominali także o wspólnotowym aspekcie praktyki w postaci poczucia przynależności do wspólnoty wartości moralnych i duchowych i możliwości rozwijania kontaktów towarzyskich. Badaczki zwracają uwagę, że mimo społecznych ograniczeń w dostępie do zajęć jogi, szczególnie dla grup społecznie wykluczonych, takich jak osoby starsze czy cierpiące na depresję lub inne zaburzenia psychiczne, a także osób przeżywających kryzys, regularna praktyka jogi może przyczyniać się do wzmocnienia poczucia społecznej przynależności i przełamywać poczucie społecznej izolacji jednostki.

Jako badaczkę intymności i seksualności od lat praktykującą jogę oraz początkującą nauczycielkę jogi interesowało mnie przybliżenie polskim czytelnikom i czytelniczkom badań dotyczących związku praktyki jogi z budowaniem i rozwijaniem związków intymnych, realizowanych za pomocą technik 
jakościowych. Niestety, mimo pogłębionej i szerokiej analizy danych zastanych, nie znalazłam żadnych badań, które wprost odnosiłyby się do tego tematu. Badania na temat szerszego spektrum relacji interpersonalnych wskazują jednak, że można mówić o ich związku z praktyką jogi. Temat ten podejmowany jest jednak przez samych joginów i joginki odnoszących się do swoich doświadczeń, a także przez praktyków - terapeutki i terapeutów używających jogi w swojej praktyce klinicznej.

Seksuolożka Lori Brotto wraz z zespołem (2009) zwraca uwagę, że wraz z nadejściem ery „leczenia opartego na dowodach" oczekuje się dowodów, że interwencje opierające się na praktyce jogi są skuteczne. Jej zdaniem ponieważ joga była praktykowana i nauczana od wielu stuleci, a także ze względu na moc osobistych świadectw o skuteczności jogi, rzadko poddaje się ją analizie empirycznej, co dzieje się szczególnie, gdy testuje się bardziej dochodowe formy wsparcia (np. leki czy nowoczesne terapie). Brotto wraz z zespołem wskazuje jednak, że niewątpliwym jest, że ci, którzy praktykują jogę, doświadczają z tego korzyści, stąd podkreśla konieczność zwiększenia zainteresowania testowaniem i demonstrowaniem korzystnych skutków jogi dla wielu różnych aspektów ludzkiej seksualności (Brotto i in. 2009). W swoim badaniu opisuje natomiast, że regularna praktyka jogi podnosi satysfakcję ze stosunków seksualnych, podczas gdy inni badacze wskazują na jej pomocność w leczeniu zaburzeń seksualnych (Dhikav i in. 2010a; 2010b), konkurencyjną wobec leczenia farmakologicznego. $Z$ kolei z wniosków na podstawie praktyki klinicznej Amy Swart wynika, że praktyka jogi w parach może pomóc partnerom dbać o granice psychologiczne w związku i uniknąć utraty własnej tożsamości przy jednoczesnym zachowaniu bliskości i intymności w relacji (Swart 2011).
Przeglądając literaturę przedmiotu, znalazłam jedynie jedną pracę wprost podejmującą kwestię związku praktyki jogi z budowaniem i rozwijaniem związków intymnych. Lauren Evron wykonała ilościowe badanie porównawcze grupy praktykujących i niepraktykujących jogę oparte o kwestionariusze poziomu stresu, poziomu uważności, autentyczności ja, autentyczności w relacji intymnej, satysfakcji i zaangażowania w związek oraz dane na temat formy i częstotliwości praktyki jogi. Celem było zbadanie, na ile i za pomocą jakich zmiennych pośredniczących praktyka jogi może wpływać na poziom satysfakcji i zaangażowania w związek (Evron 2019). Badaczka wyróżnia przy tym interesująca zmienną, którą określa jako stosowanie jogi w życiu codziennym (yoga in real life). Wskaźnik ten oparty jest o doświadczenia współczucia wobec siebie, akceptacji stanu rzeczy, koncentracji na oddechu, skierowaniu uwagi na postawę i ułożenie ciała, celowego odpuszczania fizycznego napięcia i stresu psychicznego i poczucia połączenia z wyższą mocą. W badaniu Evron dowiodła, że to właśnie tenże wskaźnik bardziej niż sama praktyka jogi (asan czy technik oddechowych podczas zajęć lub praktyki własnej) wpływa na satysfakcję z relacji. Stąd też możliwe jest stosowanie jogi w życiu codziennym, niekoniecznie praktykując samą jogę, chociaż z badania Evron wynika, że jest to bardziej powszechne wśród praktykujących jogę niż niepraktykujących. Ponadto Evron przyjrzała się działaniu zmiennych pośredniczących wpływających na satysfakcję i zaangażowanie w relacje, czyli kwestii stresu, uważności, poczucia autentycznego ja i autentyczności w związkach. Wyniki jej badania wskazują, że chodzenie na zajęcia jogi prowadzić może do praktykowania jogi w życiu codziennym, a zatem stosowanie praktyk uważności, współczucia wobec innych i siebie i bycie autentycznym w relacji ze sobą i partnerem wpływa na satysfakcję ze związku. 


\section{Praktyka jogi w polskich badaniach społecznych}

Polskie badania również wskazują, że regularna praktyka jogi wpływa na efektywniejsze radzenie sobie ze stresem w codziennym życiu (Gwis, Olejniczak, Skonieczna 2016; Ciosek i in. 2018). Podobnie jak w światowym piśmiennictwie także polskie studia nad jogą zdominowane są przez psychologiczne badania ilościowe. Na tym tle wyróżniają się badania Krzysztofa Koneckiego i szczególnie znane pionierskie studium socjologiczne oparte o metodologię jakościową, między innymi wywiady pogłębione i obserwację uczestniczącą, Czy ciało jest światynia duszy? Wspótczesna praktyka jogi jako fenomen psychospołeczny (Konecki 2012). Pracę do dziś uznaje się za najbardziej rozbudowane i pogłębione studium procesu stawania się praktykującym jogę według metody B.K.S. Iyengara, przybliżającą także charakterystykę społeczności praktykującej według tej metody w Polsce. Badaczowi udało się ukazać, jak bardzo dla społeczności praktykujących istotny jest duchowy, psychologiczny i społeczny wymiar praktyki asan, mimo że początkowo to raczej fizyczny aspekt (m.in. zdrowie fizyczne, dbałość o sylwetkę) jest tym, co motywuje ludzi do rozpoczęcia praktyki jogi. Konecki pokazuje przy tym, że dla wielu praktykujących joga jest nie tylko formą spędzania wolnego czasu czy dbania o zdrowie, ale i stylem życia włączającym dbałość o dietę czy unikanie używek (2012: 22). Trafnie zauważa, że chociaż społeczność ta jest raczej niejednorodna, nawet w obrębie osób praktykujących tą samą metodą (B.K.S. Iyengara), to składa się ona z mikrospołeczności zgromadzonych wokół konkretnych szkół jogi lub nauczycieli (2012: 42). Na podstawie wypowiedzi swoich badanych i poczynionych systematycznych i pogłębionych obserwacji, a także zakorzeniając swoje wnio- ski w obrębie własnych doświadczeń praktyki jogi, badacz stwierdza, że praktyka jogi w subiektywnym odczuciu zróżnicowanej grupy praktykujących wpływa na dobrostan psychiczny (badani wspominali o redukcji stresu, wzmocnieniu wiary w siebie i poczucia własnej wartości i rozwój samoakceptacji). Odnosi się także do kwestii stosunków interpersonalnych, przytaczając doświadczenia badanych związane z autentycznością, uważnością, otwartością i współczująca postawą w relacjach społecznych i intymnych (2012: 107-188). Badaczowi udało się również trafnie uchwycić dynamikę wymiany jakości w praktyce jogi, gdzie poziom indywidualnego, subiektywnego i bardzo intymnego doświadczenia spotyka się ze wsparciem społecznego świata hatha jogi. Odbywa się to bez konieczności werbalnego definiowania wielu przeżyć doświadczanych na macie, ale także poprzez sięganie do nauk wyniesionych z praktyki jogi na macie w życiu codziennym (2012: 85).

Także w kolejnych swoich publikacjach Konecki wraca ponownie do tematu pozytywnego wpływu jogi na społeczny dobrostan i życie społeczne jednostki, wskazując, że joga umożliwia budowanie świadomości ciała i związku ciała i umysłu również $\mathrm{w}$ zakresie emocjonalnym, co ma pozytywnym wpływ na rozwijanie kompetencji i zasobów do uczenia się studentów uczelni wyższych tychże zagadnień podczas zajęć teoretycznych (Konecki 2018a). Autor, inspirując się wnioskami ze swoich badań, przedstawia także propozycję stworzenia nowego paradygmatu badawczego w projekcie socjologii kontemplacyjnej (Konecki 2018b), tworząc tym samym ważne podstawy do tworzenia studiów badawczych opartych o autoobserwację i autoetnografię, które mogą być szczególnie cenne dla badań na temat jogi ze względu na jej introspekcyjny charakter i immanentną wartość ucieleśnionej 
wiedzy nabywanej poprzez psychofizyczne doświadczenie.

\section{Podsumowanie}

Celem niniejszego artykułu był przegląd badań na temat coraz bardziej popularnej w Polsce i na świecie praktyki jogi, której wpływ na relacje społeczne wciąż pozostaje nie $\mathrm{w}$ pełni objęty badawczą eksploracją szczególnie w dziedzinie socjologii jakościowej. Wychodząc od pola badań dotyczącego wpływu jogi na dobrostan psychiczny jednostki, poprzez przybliżenie czytelnikom rozwijającego się dynamiczne pola krytycznych studiów nad jogą, by na koniec skoncentrować się na badaniach dotyczących związku praktyki jogą z praktykowaniem relacji interpersonalnych, starałam się wskazać na najciekawsze, z mojej badawczej perspektywy, wnioski z badań, ale także na widoczne luki i czekające na przyszłych badaczy i badaczki wyzwania. Sądzę, że społeczne studia nad jogą i wpływem praktyki jogi na relacje społeczne mogą stanowić interesujące pole badawcze dla badaczek i badaczy związanych z socjologią rodziny, intymności i pary oraz seksualności i płci, ale także socjologii medycyny, religii i sportu. W swej istocie stanowią one zatem projekt interdyscyplinarny, zaś ze względu na specyfikę badanej tematyki, szczególnie warte podjęcia są one w mojej opinii przez socjologów i socjolożki związane $\mathrm{z}$ badaniami jakościowymi, gdzie możliwe jest uchwycenie znaczeń, dynamiki, a także głębi i niuansów relacji praktykujących jogę z otoczeniem społecznym.

Sądzę, że przyszłe badania na temat zjawiska jogi w perspektywie socjologicznej, które mam nadzieję będą rozwijać się także w Polsce, winny objać refleksją dwie kwestie. Po pierwsze, wyciągając wnioski z badań już przeprowadzonych, warto skierować badawcze wysiłki w stronę pogłębionych studiów opartych o techniki jakościowe lub łączących techniki jakościowe i ilościowe (metodologia mieszana, mixed method approach). Umożliwiłoby to przyjrzenie się temu, w jaki sposób praktyka jogi oddziałuje na jednostkę. Dzięki zastosowaniu różnych technik badawczych (obserwacji uczestniczącej, etnografii, wywiadów pogłębionych czy też wywiadów biograficznych) oraz włączeniu w badania perspektyw osób stale towarzyszących osobom praktykującym (np. objęcie badaniami także partnerów lub też rodziny i przyjaciół) możliwe byłoby uchwycenie złożonej dynamiki związku praktyki jogi z dobrostanem indywidualnym i życiem społecznym jednostki i wejście w głębsze niuanse doświadczania jogi przez praktykujących i przełożenie tegoż doświadczania na życie.

Po drugie, ze względu na to, że rynek jogi w Polsce znacząco różni się od rynku amerykańskiego, gdzie prowadzona jest większość badań z zakresu krytycznych studiów nad jogą, konieczne byłoby włączenie w ramy badań geograficznej i społeczno-kulturowej wrażliwości. Badania prowadzone w Stanach Zjednoczonych lub Europie Zachodniej wskazują, że zachodni rynek jogi jest bardzo skomercjalizowany, zaś dostępność zajęć jest ograniczona klasowo i rasowo. W Polsce jednak rynek ten nie jest tak duży, ceny zajęć są nieco bardziej przystępne. Nie istnieje też lokalny szczególnie rozbudowany dyskurs na temat jogi oparty o kult pięknego ciała i konieczność posiadania kosztownych strojów i akcesoriów, i także w tym sensie może być on bardziej otwarty i inkluzywny. Sądzę, że warto przyjrzeć się charakterystyce lokalnego rynku jogi i społeczno-demograficznej charakterystyce społeczności jogicznej w Polsce w celu uniknięcia replikowania wnioskowania i importu założeń z badań zachodnich. 


\section{Bibliografia}

Andrews Gavin J. i in. (2004) The geography of complementary medicine: perspectives and prospects. "Complementary Therapies in Nursing \& Midwifery", vol. 10, s. 175-185.

Atkinson Michael (2010) Entering scapeland: yoga, fell and post-sport physical cultures. „Sport in Society”, vol. 13, s. 1249-1267.

Atkinson Nancy L., Permuth-Levine Rachel (2009) Benefits, barriers, and cues to action of yoga practice: a focus group approach. „American Journal of Health Behavior", vol. 33, s. 3-14.

Benson Herbert (1975) The Relaxation Response. New York: William Morrow \& Co.

Berila Beth (2018) Yoga, the Body, and Embodied Social Change: An Intersectional Feminist Analysis. Laham: Rowan and Littlefield.

Bieńko Mariola (2013) Intymne i prywatne praktyki codzienności. Warszawa: Wydawnictwo Uniwersytetu Warszawskiego.

Bishop Scott R. i in. (2004) Mindfulness: A Proposed Operational Definition. "Clinical Psychology: Science and Practice”, vol. 11, s. 230-241.

Bosonamacie.pl (2016) Joga się liczy! [dostęp 9 listopada 2020 r.]. Dostępny w Internecie: ‘https://bosonamacie.pl/wp-content/uploads/2016/04/Raport-ca\%C5\%82y-JOGA-si\%C4\%99-LICZY-1.pdf..

Brotto Lori i in. (2009) Yoga and Sexual Functioning: A Review. "Journal of Sex \& Marital Therapy", vol. 35, s. 378-390.

Childress Traci Michelle (2007) Power in Hatha Yoga Communities and Classes: Understanding Exclusion and Creating Space for Diverse Cultures. „International Journal of Yoga Therapy”, vol. 17, s. 51-56.

Ciołkosz Matylda (2020) Joga: starożytna ścieżka duchowa czy wygibasy z Instagrama? [dostęp 9 listopada 2020 r.]. Dostępny w Internecie: https://religioznawstwo.uj.edu.pl/ogloszenia/-/journal_ content/56_INSTANCE_zw3tf9n4c849/139758312/145445013〉.

Ciosek Żaneta i in. (2018) Czy regularne trenowanie jogi może mieć zwiazek z efektywniejszym radzeniem sobie ze stresem? „Pomeranian Journal of Life Sciences", vol. 4, s. 454-459.

Czapiński Janusz, Panek Tomasz, red. (2015) Diagnoza Społeczna 2015, Warunki i Jakość Życia Polaków - Raporty. „Contemporary Economics", vol. 9, s. 1-547.
Daubenmier Jennifer J. (2005) The Relationship of Yoga, Body Awareness, and Body Responsiveness to Self-Objectification and Disordered Eating. „Psychology of Women Quarterly”, vol. 29, s. 207-219.

Denzin Norman K., Lincoln Yvonna S. (2009) Wprowadzenie. Dziedzina i praktyka badań jakościowych [w:] Norman K. Denzin, Yvonna S. Lincoln, eds., Metody badań jakościowych. Warszawa: Wydawnictwo Naukowe PWN, s. 19-77.

Dhikav Vikas i in. (2010a) Yoga in male sexual functioning: a noncompararive pilot study. „The Journal of Sexual Medicine”, vol. 7, s. 3460-3466.

Dhikav Vikas i in. (2010b) Yoga in Female Sexual Functions. „The Journal of Sexual Medicine", vol. 7, s. 964-970.

Evron Lauren (2019) Yoga, Mindfulness and Interpersonal Relationships. New York: University of Rhode Island.

Field Tiffany (2016) Yoga research review. „Complementary Therapies in Clinical Practice”, vol. 24, s. 145-161.

Foucault Michel (2010) Historia seksualności. Przełożyli Bogdan Banasiak, Tadeusz Komendant i Krzysztof Matuszewski. Gdańsk: Wydawnictwo Słowo/Obraz Terytoria.

Friese Malte, Hofmann Wilhelm (2016) State mindfulness, self-regulation, and emotional experience in everyday life. „Motivation Science", vol. 2, s. 1-14.

Gard Tim i in. (2014) Potential self-regulatory mechanisms of yoga for psychological health. - „Frontiers in Human Neuroscience”, vol. 8, s. 1-20.

Goleman Daniel (2015) Focus: The Hidden Driver of Excellence. New York:Harper Paperbacks.

Gotlib Ian H., Hammen Constance L., eds. (2015) Handbook of Depression, Third Edition. New York: The Guilford Press.

Grabara Małgorzata (2017) Hatha Yoga as a Form of Physical Activity in the Context of Lifestyle Disease Prevention. „Polish Journal of Sport and Tourism", vol. 24, s. 65-71.

Granek Leeat (2006) What's Love Got to Do With It? The Relational Nature of Depressive Experiences. "Journal of Humanistic Psychology", vol. 46, s. 191-208. 
Gwis Katarzyna, Olejniczak Dominik, Skonieczna Joanna (2016) Motywacja i wptyw uprawiania jogi na stan zdrowia - badanie własne. „Journal of Education, Health and Sport", vol. 6, s. 554-565.

Hoyez Anne-Cécile (2007) The 'world of yoga': The production and reproduction of therapeutic landscapes. "Social Science \& Medicine", vol. 65, s. 112-124.

Impett Emily A. i in. (2006) Minding the body: Yoga, embodiment, and well-being. -,"Sexuality Research and Social Policy”, vol. 3, s. 39-48.

Iyengar B.K.S. (2011) Światło Jogasutr Patańdżalego. Przełożył Konrad Kocot. Warszawa: Galaktyka.

Jakubczak Marzenna (1999) Sankhja i joga: podstawy filozofii Patańdżalego. Kraków: Wydawnictwo Oddziału Polskiej Akademii Nauk.

Jakubowska Honorata (2009) Socjologia ciała. Poznań: Wydawnictwo Naukowe UAM.

Jakubowska Honorata, Nosal Przemysław, red. (2018) Socjologia sportu. Warszawa: PWN.

Kinser Patricia Anne i in. (2012) How Might Yoga Help Depression? A Neurobiological Perspective. "Explore (New York, N.Y.)”, vol. 8, s. 118-126.

Kinser Patricia Anne i in. (2013) "A feeling of connectedness": Perspectives on a gentle yoga intervention for women with major depression. „Issues in Mental Health Nursing”, vol. 34, s. 402-411.

Kishida Moé i in. (2018) "Yoga resets my inner peace barometer": A qualitative study illuminating the pathways of how yoga impacts one's relationship to oneself and to others. "Complementary Therapies in Medicine", vol. 40, s. 215-221.

Kishida Moé i in. (2019) The Daily Influences of Yoga on Relational Outcomes Off of the Mat. "International Journal of Yoga”, vol. 12, s. 103-113.

Konecki Krzysztof (2012) Czy ciało jest światynia duszy? Współczesna praktyka jogi jako fenomen psychospołeczny. Warszawa: Difin.

Konecki Krzysztof (2018a) Hatha-Yoga in Higher Education. „Roczniki Nauk Społecznych”, vol. 10(46), no. 2, s. 109-130.

Konecki Krzysztof T. (2018b) Advances in Contemplative Social Research. Kraków: Wydawnictwo Uniwersytetu Jagiellońskiego.

Lea Jennifer (2009) Liberation or Limitation? Understanding Iyengar Yoga as a Practice of the Self. „Body \& Society”, vol. 15 (3), s. 71-92.
Lea Jennifer i in. (2016) 'It's a fine line between... Self discipline, devotion and dedication': negotiating authority in the teaching and learning of Ashtanga yoga. „Cultural Geographies”, vol. 23, s. 69-85.

Lewis Clara S. (2008) Life chances and wellness: meaning and motivation in the 'yoga market'. "Sport in Society”, vol. 11, s. 535-545.

Lucas Alexander R. i in. (2016) Mindfulness-Based Movement: A Polyvagal Perspective. „Integrative Cancer Therapies”, vol. 17, s. 5-15.

Mallinson James Sir, Singleton Mark (2017) Roots of Yoga. London: Penguin Classics.

GlobeNewswire (2020) Global Health and Wellness Market (2020 to 2025) - Industry Trends, Share, Size, Growth, Opportunity and Forecast [dostęp 9 listopada 2020 r.]. Dostępny w Internecie: ‘http:// www.globenewswire.com/news-release/2020/04/03/2011361/0/ en/Global-Health-and-Wellness-Market-2020-to-2025-IndustryTrends-Share-Size-Growth-Opportunity-and-Forecast.html.

Markula Pirkko (2004) "Tuning into One's Self:" Foucault's Technologies of the Self and Mindful Fitness. "Sociology of Sport Journal", vol. 21, s. 302-321.

Markula Pirkko (2014) Reading Yoga: Changing Discourses of Postural Yoga on the Yoga Journal Covers. "Communication \& Sport", vol. 2, s. 143-171.

Mehta Urvakhsh Meherwan i in. (2016) Bridging the schism of schizophrenia through yoga-Review of putative mechanisms. „International Review of Psychiatry (Abingdon, England)", vol. 28, s. 254-264.

Menezes Carolina B. i in. (2015) Yoga and emotion regulation: A review of primary psychological outcomes and their physiological correlates. „Psychology \& Neuroscience”, vol. 8, s. 82-101.

Michalsen Andreas i in. (2005) Rapid stress reduction and anxiolysis among distressed women as a consequence of a three-month intensive yoga program. „Medical Science Monitor: International Medical Journal of Experimental and Clinical Research", vol. 11, s. CR555-561.

Michelis Elizabeth De (2005) A History of Modern Yoga: Patanjali and Western Esotericism. London: Continuum.

Montigny Djahill (2016) The unstoppable trend of yoga. YOGI TIMES [dostęp 9 listopada 2020 r.]. Dostępny w Internecie: https://www.yogitimes.com/article/unstoppable-trend-yoga-infographic-business〉.

Morgan David (2011) Rethinking Family Practices. Basingstoke, New York: Palgrave Macmillan. 
Morone Natalia E. i in. (2012) Mindfulness to reduce psychosocial stress. „Mindfulness”, vol. 3, s. 22-29.

Neff Kristin D. i in. (2007) Self-compassion and adaptive psychological functioning. "Journal of Research in Personality", vol. 41, s. 139-154.

Nevrin Klas (2008) Empowerment and using the body in modern postural yoga [w:] Mark Singleton, Jean Byrne, eds. Yoga in the Modern World: Contemporary Perspectives. London: Routledge, s. 119-139.

Ospina Maria B. i in. (2007) Meditation practices for health: state of the research. „Evidence Report/Technology Assessment”, vol. 155, s. 1-263.

Ostrowska Antonina (2019) Socjologia medycyny. Warszawa: Wydawnictwo Naukowe PWN.

Parshad Omkar (2004) Role of yoga in stress management. „The West Indian Medical Journal", vol. 53, s. 191-194.

Pilkington Karen i in. (2005) Yoga for depression: the research evidence. "Journal of Affective Disorders", vol. 89, s. 13-24.

Porges Stephen W. (2009) The polyvagal theory: new insights into adaptive reactions of the autonomic nervous system. "Cleveland Clinic Journal of Medicine”, vol. 76, suppl. 2, s. S86-90.

Rhodes John, Smith Jonathan A. (2010) "The top of my head came off": An interpretative phenomenological analysis of the experience of depression. "Counselling Psychology Quarterly", vol. 23, s. 399-409.

Ross Alyson i in. (2013) National survey of yoga practitioners: mental and physical health benefits. "Complementary Therapies in Medicine", vol. 21, s. 313-323.

Ross Alyson i in. (2014) "I Am a Nice Person When I Do Yoga!!!": A Qualitative Analysis of How Yoga Affects Relationships. "Journal of Holistic Nursing", vol. 32, s. 67-77.

Sauer-Zavala Shannon E. i in. (2013) Comparing Mindfulness-Based Intervention Strategies: Differential Effects of Sitting Meditation, Body Scan, and Mindful Yoga. „Mindfulness”, vol. 4, s. 383-388.

Schiffmann Erich, O'Rielly Trish (1996) Yoga: The Spirit and Practice of Moving into Stillness. New York: Pocket Books.

Schmidt Filip i in. (2018) W strone socjologii pary: propozycja paradygmatu teoretyczno-badawczego. "Studia Socjologiczne", t. 3(230), s. 11-39.
Schnäbele Verena (2013) The Useful Body: The Yogic Answer to Appearance Management in the Post-Fordist Workplace [w:] Beatrix Hauser, ed., Yoga Traveling: Bodily Practice in Transcultural Perspective. Heidelberg: Springer International Publishing, s. 135-153.

Shastri Vasant Venkatraman i in. (2017) Investigation of Yoga Pranayama and Vedic Mathematics on Mindfulness, Aggression and Emotion Regulation. „International Journal of Yoga”, vol. 10, s. 138-144.

Sikorska Małgorzata (2019) Praktyki rodzinne i rodzicielskie we wspótczesnej Polsce - rekonstrukcja codzienności. Warszawa: Scholar.

Singleton Mark (2010) Yoga Body: The Origins of Modern Posture Practice. Oxford, New York: Oxford University Press.

Smith Jeannette M., Alloy Lauren B. (2009) A roadmap to rumination: a review of the definition, assessment, and conceptualization of this multifaceted construct. "Clinical Psychology Review”, vol. 29 , s. $116-128$.

Smith Sabrina, Atencio Matthew (2017) Yoga is yoga. Yoga is everywhere. You either practice or you don't": a qualitative examination of yoga social dynamics. "Sport in Society", vol. 20, s. $1167-1184$.

Stasińska Agata (2018) Socjologia pary. Praktyki intymne w zwiazkach nieheteroseksualnych. Kraków: Nomos.

Strauss Sarah (2002) "Adapt, adjust, accommodate": the production of yoga in a transnational world. „History and anthropology”, vol. 13, s. 231-251.

Swart Amy (2011) Partner yoga for establishing boundaries in relationship: a transpersonal somatic approach. „International Journal of Yoga Therapy", vol. 21, s. 123-128.

Szlendak Tomasz (2010) Socjologia Rodziny. Ewolucja, historia, zróżnicowanie. Warszawa: PWN.

Szopa Janusz (2008) Rekreacja ruchowa poprzez ćwiczenia fizyczne jogi [w:] Władysław Mynarski, red., Teoretyczne i empiryczne zagadnienia rekreacji i turystyki. Katowice: AWF, s. 60-77.

Vempati R. P., Telles Shirley (2016) Yoga-Based Guided Relaxation Reduces Sympathetic Activity Judged from Baseline Levels. „Psychological Reports", vol. 90(2) s. 487-494.

Woolery Alison i in. (2004) A yoga intervention for young adults with elevated symptoms of depression. „Alternative Therapies in Health and Medicine", vol. 10, s. 60-63. 


\title{
Cytowanie
}

Stasińska Agata (2020) Czy joga może być „sztuka życia”? Przeglad badań na temat jogi jako zjawiska społecznego. „Przegląd Socjologii Jakościowej", t. 16, nr 4, s. 170-190 [dostęp dzień, miesiąc, rok]. Dostępny w Internecie: ‘www.przegladsocjologiijakosciowej. org>. DOI: http://dx.doi.org/10.18778/1733-8069.16.4.09

\section{Can Yoga Be an "Art of Living"? A Review of Research on Yoga as a Social Phenomenon}

\begin{abstract}
Yoga practice is an increasingly popular form of physical activity both in Poland and in the world. It has a positive effect on health, but it is also an element of personal development as well as, quite often, a spiritual practice. However, research on yoga practice is dominated by health sciences, while in social sciences it exists mainly through psychological research based on quantitative techniques, which often finds it difficult to grasp the nuanced mind-body relationship present in the experience of yoga practice. It is rare that attempts are made to examine the relationship between yoga practice and building social relationships by an individual.
\end{abstract}

This article aims at familiarizing Polish readers with those research fields where yoga practice is being investigated as a social phenomenon. I consider yoga as a historical and social phenomenon. Most of all, however, I recognize research on the impact of yoga practice on an individual as well as that which offers a critical analysis of yoga communities. I then conclude with studies on the relationship between yoga practice and interpersonal relations. To complete my review, I also present recommendations for future research on yoga practice.

The article might be an inspiration for future researchers interested in the practice of yoga as a social phenomenon, e.g. sociologists representing various fields of sociology, such as the sociology of family, intimacy and couples, as well as sports, medicine, and religion.

Keywords: yoga, interpersonal relations, critical yoga studies, yoga as a social phenomenon, sociology of family, sociology of intimacy, psychological well-being 